\title{
O RESPEITO \\ À CURIOSIDADE \\ INFANTIL
}

\section{A curiosidade infantil desperta o educador para a necessidade de uma aula criativa e estimuladora, na qual a aquisição de conhecimento é processo de cooperação e crescimento coletivo}

A criança é naturalmente curiosa, desejosa de saber, conhecer, experimentar.

Sábia, ela tem noção, ainda pequena, de que há muito o que conhecer no mundo.

Para perceber isso, basta deixá-la falar, perguntar, questionar, sem medo de ouvir perguntas escabrosas ou "difíceis de responder".

A escola, enquanto espaço de promoção do saber, tem a função de proporcionar momentos de dúvidas e descobertas. O educador, enquanto mediador da aprendizagem, tem como uma de suas funções, instigar a dúvida, provocar o educando para a indagação do que anseia aprender e mostrar-lhe que há várias fontes de saber.

Quando o educador permite que a curiosidade de seus alunos invada a sala de aula e faça parte de seu trabalho, ele está apostando em uma forma agradável de aprender e ensinar.

Aprender deixa de ser uma obrigação, um acontecimento distante da realidade do educando e passa a ser uma sucessão de descobertas.

Para manter esse tipo de prática, o educador precisa desprender-se das grades curriculares. Não ignorá-las, mas considerar-se livre e capaz o suficiente para ultrapassá-las. E ultrapassá-las juntamente com seus alunos, permitindo-lhes participar de maneira ativa e presente em todos os passos de sua aprendizagem.

Ao abrir os ouvidos para as curiosidades de seus alunos, o educador terá que abrir sua mente para aceitar seus limites e verificar que não é o dono da verdade, o ditador de regras e o "dicionário ambulante", mas sim um

\begin{tabular}{l} 
A AUTORA \\
\hline Cristiane Fernandes Tavares \\
Educadora, graduada em Comunicação Social e \\
pós-graduanda em Psicopedagogia.
\end{tabular}
indivíduo pronto a aprender com seus alunos, desde o momento em que lhes permite a interrogação até o momento em que procura respondê-la junto com eles. 
Desse modo, ocorre uma articulação com o real, o saber não se dissolve em acúmulo de informações mais ou menos eruditas, mas assume um caráter consistente e marcante, que vai ao encontro das necessidades interiores das crianças.

Foi justamente com o objetivo de ultrapassar os conteúdos pré-estabelecidos para a primeira série do primeiro grau que criei em minha sala de aula um espaço para o surgimento de assuntos diversos que interessassem aos alunos. Essa experiência ocorreu na Fundação Bradesco (Osasco) no ano de 1993, com meus 40 alunos da primeira série G.

A leitura do livro A curiosidade premiada ${ }^{1}$ foi o ponto de partida. $\mathrm{O}$ livro pertencia à nossa biblioteca de classe e tratava-se de um livro bem elaborado, interessante e, principalmente, suscitador.

Glorinha é a personagem principal, uma criança que é a curiosidade em pessoa: bombardeia seus pais com perguntas de todo tipo. Esses se vêem desesperados, procuram a ajuda de uma vizinha muito sábia e começam a perguntar junto com a filha. Respondem muitas perguntas e descobrem muitas coisas também, inclusive que não sabem tudo... Ao final da história, Glorinha deixa de ser a filha chata e contagia a todos com suas dúvidas. A família a ouve e crescem juntos.

\section{HORA DA CURIOSIDADE}

Durante a leitura da história, os alunos divertiram-se com as perguntas de Glorinha e muitos identificaram-se com ela. Após a leitura, sugeri que cada aluno pensasse rapidamente em uma curiosidade que tivesse. Um a um iam falando e eu registrava na lousa. Surgiram perguntas de todo o tipo: "por que os peixes vivem na água e a gente não?", "como era a época dos dinossauros?", "como se faz o giz da lousa?" etc. As perguntas foram saindo sem censura e sem receio, ansiosas por serem ouvidas e respondidas. Como era impossível responder a todos de uma vez, decidimos que o que interessasse a mais pessoas deveria ter prioridade. Teríamos um dia da semana para conversarmos sobre a curiosidade eleita. Esse momento recebeu o nome de "hora premiada", modificada depois para "hora da curiosidade".

O primeiro tema escolhido em votação foi: como eram as primeiras bicicletas? Com uma semana de antecedência cada um pesquisaria em casa e traria para a roda o que tivesse conseguido. Sempre em roda, as crianças falavam sobre o tema, abordavam vários aspectos, viam figuras e ouviam a complementação da professora. Especificamente neste assunto aproveitei para introduzir um conteúdo da série: os meios de transportes.

Das bicicletas, passamos aos carros, trens, aviões, metrôs etc. Esse é um dos aspectos positivos da "hora da curiosidade": poder utilizar o tema 
em discussão para a introdução de outros temas que constam no currículo da série.

Depois desse primeiro tema, fomos percebendo que seria difícil estudarmos um assunto por semana, pois eles prolongavam-se e puxavam outras discussões. Fomos diminuindo o número de temas abordados, mas aprofundando o estudo dos mesmos.

Um problema que enfrentamos foi o que fazer com as perguntas sugeridas que não venciam nas votações. Ficariam sem resposta? Claro que não!

A solução foi sugerir o estudo individual dos temas que não fossem estudados por todos. Em casa com os pais ou na biblioteca da escola, esses alunos eram orientados a descobrir a resposta às suas dúvidas.

Alguns assuntos escolhidos eram abstratos demais para serem encontrados em livros de pesquisa em geral. Tratava-se de assuntos de ordem religiosa ou existencial, que implicavam opiniões bem pessoais. Um exemplo foi o tema "por que os padres não podem casar?". Para responder, os alunos usaram a entrevista com padres conhecidos.

\section{PREPARAR-SE PARA APRENDER}

Foi um assunto polêmico, que envolveu diferença de crença religiosa. Sem dúvida, uma discussão muito rica. Os alunos conheceram, entenderam e puderam opinar. Mais uma característica positiva da "hora da curiosidade": promover o exercício da crítica, após o conhecimento do assunto, respeitando opiniões diferentes.

Inspirada na própria mola que impulsionou o aparecimento da "hora da curiosidade", ou seja, o desejo do saber e do saber gostoso, passei a abordar com a classe um mesmo tema sob vários aspectos que não só o informativo-científico (através de livros). Comecei a trazer para a sala poesias, músicas, histórias infantis, filmes etc., para responder às curiosidades sob vários olhares: o poético, o musical, o literário, o cinematográfico.

Na realização deste trabalho não pode haver pressa em esgotar um assunto, quanto mais abordagens forem feitas, mais completa será a informação que estamos transmitindo e aprendendo. A preparação do educador para discutir cada tema é fundamental, até porque algumas vezes as crianças trazem pouco material e é preciso garantir a discussão. Os pais também precisam ser orientados quanto às formas de pesquisa e fontes de informação.

Depois que entrei em contato com as curiosidades de meus alunos, suas dúvidas tão sábias, tão carregadas de observação, ou mesmo as mais ingênuas e puras, reafirmei minhas conviç̧ões sobre o rico universo da educação humanista, sensível, não menos política e eficiente. A educação que forma cidadãos críticos.

E por acreditar (verificando com os próprios olhos, avaliando com todo o intelecto e sentindo com todo o emocional) que, nós educadores, temos o papel crucial de contribuir na formação de homens livres e na consolidação da democracia, que o ato de educar se revela cada dia mais surpreendente e poderoso para mim. 